\title{
New Subgroups Classıfıed in Adult Diabetes Mellitus
}

\author{
Mehmet Serdar Cengizhan', ${ }^{1}$ Mehmet Celik ${ }^{* 2}$ \\ ${ }^{1}$ Bilecik Statehospital, Department of InternalMedicine, Turkey \\ ${ }^{2}$ Bilecik Statehospital, Department of EndocrinologyandMetabolism, Turkey. \\ drmehmetcelik@hotmail.com \\ *Corresponding Author: Mehmet Celik, Bilecik Statehospital, Department of Endocrinology and Metabolism, Turkey.
}

\begin{abstract}
Diabetes mellitus was classified in two groups, type 1 and type 2 diabetes, but Emma Ahlqvist et al. Argue that type 2 diabetes mellitus is quite heterogeneous in particular. A study published in the Lancet emphasized that diabetes in adults should be separated into 5 separate groups and that the type of diabetes should be changed. It was stated that this new classification would allow for more individualized treatments. This may, of course, lead to a new approach, which may reduce the complications of treatment for the individual.
\end{abstract}

Keywords: Novel subgroups, diabetes mellitus

At The Present Time, frequency of seeing of Diabetes and Metabolic Disseases is increasing steadily. For example the prevalence of Obesity is nearly 35\% (BMI>30) and $70 \%$ (BMI $>25)$, likewise the prevalance of Diabetes Mellitus $>7 \%$, Hyperlipidemia appromaximately 20$25 \%$ and Metabolic Syndrome is about 35\% $(1,2)$.

The Obesity is the key for many kinds of DM. Appetite is affected by many factors. For example where as the NPY, Orexin, Endocannabinoids, CCK and Gherelin increases the Appetite, on the otherwise $\alpha$-MSH, GLP-1, Serotonin, İnsulin and Leptin decreases the appetite. When the scientiests found the identification of the ob gene mutation in genetically obese (ob/ob) mice, it was one of the greatest breaking point in the obesty-related syndromes. In those mouses has been developed severe obesity, insulin resistance and hyperphagia. $\mathrm{Ob}$ gene products Leptin, that secreted from adipose cells and acts primarily through the Hypothalamus. When the Leptin levels increases, it decreases food intake and increase energy expenditure. Many individuals with morbid, early onset obesty, caused by inactivating mutations in either leptin or the leptin receptor described. The genes cause obesty in human is POMC, MC4R,PC1 ,Trk- $b$ and the others. Some of the Obesty sendroms are Prader-Willi, Lauronce-Moon-Biedl, Cohen's and Carpenter's ( these syndromes are also related with hipogonadizm and Mental Retardation) (3-6).
Today, the scientists thinks that Patients with type 2 diabetes mellitus are usually under continuous long-term medical treatment based on anti- diabetic drugs or insulin treatments to achieve the desired glucose level. Thus, each patients treatment must be personelized about their DM type and subtypes. In a study conducted by researchers at the Swedish Lund University Diabetes Center in Lancet, a new study reported that adult diabetics were divided into 5 separate groups. Scientists now emphasize the need to change the perception that diabetes is type 2. In Sweden and Finland, the data for 8,880 adult diabetic patients were evaluated. Researchers said that categorizing diabetes more specifically would prevent many patients from getting more personalized treatment and complications from general treatment (7).

The 5 sub groups that are classified are genetically different. Researchers evaluating genetic analysis found that the five subgroups they categorized were genetically different. It was also discovered that newborns with diabetes and those with long-lasting illnesses could be included in different classifications. Researchers think that over time, there might be a shift between diabetes types.The current diabetes classification consists of two types. Type 1 diabetes is an autoimmune disorder in

which insulin hormone is not produced, and it is known that it usually occurs in childhood. Type 2 diabetes, 
which is associated with obesity and develops at an older age, the production of low levels of insulin in the body and the in ability of the cells to be triggered sufficiently for glucose absorption. However, a recent study notes that this classification is very basic and leads to the failure of appropriate treatments in patients. Each group is treated differently (7).

In a study entitled "Novel subgroups of adult-onset diabetes and their association without comes," (7) the Lancet Diabetes and Endocrinology, published in theJournal of the United States, reported that type 1 diabetes and a late autoimmune form of diabetes it can be accepted as a group. However, it is pointed out that the type categorized as type 2 should be classified as 4 different heavy types. Here are the 4 subgroups currently proposed as type 2 in the survey:

1. The first group consists of diabetic patients with severe insulin deficiency; with the same type of autoimmune group, type-1, with similar low body mass index (BMI), insulin deficiency and early onset. However, it does not contain antibodies pointing to the presence of an autoimmune disease. Diabetic eye disease is most common in this group. Most of these patients use metformin. But researchers need to start taking insulin as soon as possible, as in type 1 , if this is not enough treatment (7).

2. Another serious category, called severe insulinresistant diabetes, is associated with obesity. Body cells in this group do not respond to insulin. These patients; liver disease, chronic kidney disease and diabetic kidney. Researchers suggest that this group'suse of metformin is low, and that this should be taken more seriously (7).

3 and 4 . The other two categories are the lighter forms of the two groups above. The first group is known as obesity-associated mild diabetes and is based on high body mass index (7).

The latter group is referred to as age-related mild diabetes and usually occurs in elderly patients. The researchers recommend using these two groups of metformin and lifestyle modification (7).

\section{REFERENCES}

[1] Ng, Marie, et al. "Global, regional, and national prevalence of overweight and obesity in children and adults during 1980-2013: a systematic analysis for the Global Burden of Disease Study 2013." The lancet 384.9945 (2014): 766-781.

[2] Moore JX, Chaudhary N, Akinyemiju T. Metabolic Syndrome Prevalence by Race/Ethnicity and Sex in the United States, National Health and Nutrition Examination Survey, 1988-2012. Prev Chronic Dis. 2017 Mar 16;14:E24.

[3] Subramaniapillai M, McIntyre RS. A review of the neurobiology of obesity and the available pharmaco therapies. CNS Spectr. 2017 Dec;22(S1):29-38.

[4] Miller, Gary D. "Appetite Regulation: Hormones, Peptides, and Neurotransmitters and Their Role in Obesity." American Journal of Lifestyle Medicine (2017): 1559827617716376.

[5] Rajeev, SuryaPanicker, Ian W. Seetho, and John $\mathrm{PH}$ Wilding. "Regulation of Food IntakeThe Gut-Brain Axis." Nutrition and Cardio metabolic Health (2017).

[6] Kaur, Y. D., et al. "A systematic review of genetic syndromes witho besity." Obesity Reviews 18.6 (2017): 603-634.

[7] Ahlqvist E, Storm P, Käräjämäki A, Martinell M, Dorkhan M, Carlsson A, Vikman P, Prasad RB, Aly DM, Almgren P, Wessman Y, Shaat N, Spégel P, Mulder H, Lindholm E, Melander O, Hansson O, Malmqvist U, Lernmark Å, Lahti K, Forsén T, Tuomi T, Rosengren AH, Groop L. Novel subgroups of adult-onset diabetes and their association without comes: a data-driven cluster analysis of six variables. Lancet Diabetes Endocrinol. 2018 Mar 1.

Citation: Mehmet Serdar Cengizhan, Mehmet Celik. New Subgroups Classified in Adult Diabetes Mellitus. Archives of Diabetes and Endocrine System. 2018; 1(1): 1-2.

Copyright: (C) 2018 Mehmet Serdar Cengizhan, Mehmet Celik. This is an open access article distributed under the Creative Commons Attribution License, which permits unrestricted use, distribution, and reproduction in any medium, provided the original work is properly cited. 